ARTICLE

\title{
Pedagogical conditions for the formation of senior preschool children's foreign language competence*
}

\author{
Rania Gennadievna Izmailova a \\ Tatyana Gennadievna Sheinova ${ }^{b}$ \\ Ksenia Yurievna Soldatenko ${ }^{b}$
}

\section{Abstract}

The aim of the research is to identify, theoretically substantiate and empirically study the pedagogical conditions for the formation of senior preschoolers' foreign language competence. The methods consist in authorial diagnostic procedures aimed at studying the interaction participants' foreign language competence. The research identified the specifics of the interaction between subjects of preschool education. The authors revealed the influence of parents' participation on the foreign language competence, motivation, attitude, and openness to learn foreign languages as well as preschoolers' psychological anxiety toward the perception of foreign speech. The authors expanded the ideas on forming preschool children's foreign language competence in pedagogical theory and practice and on the realization of the opportunities of interaction participants based on the social-pedagogical partnership, which allows improving joint activities between modern preschool organizations and families.

Keywords: Competence building approach. Senior preschoolers' foreign language competence. Early foreign language learning. Interaction between preschool teachers and family members.

\footnotetext{
* The research was financed within the framework of the competition of intramural research projects "Small Grant of the State University of Humanities and Technology".

a Moscow State University of Humanities and Technology, Orekhovo-Zuevo, Russia.

b Moscow State University of Humanities and Technology, Orekhovo-Zuevo, Russia.

c Moscow State University of Humanities and Technology, Orekhovo-Zuevo, Russia.
} 


\section{Introduction}

The main task of modern preschool education is to provide children's quality education, development and upbringing (KREN; VOVK, 2018). Today the problem of integrating a foreign language into the educational process is more oriented towards secondary school (BORISOVA, 2016; SAFONOVA, 2017). At the same time, there is a need to develop technologies of children's early development and diagnostic tools to determine preschool children's language cognitive and other skills with pedagogical support and assistance (MCCOY et al., 2018). In this regard, creating pedagogical conditions in the process of the formation of senior preschoolers' foreign language competence is a priority. Under these conditions, the main task of kindergarten is to establish a productive interaction between teachers and families. Without the participation of families, no full development of children's competences, including foreign language competence, is possible.

Consequently, the research is aimed at the identification, empirical study of pedagogical conditions for the formation of senior preschool children's foreign language competence.

Accordingly, the achievement of the research goal presupposes:

Hypothesis 1: the formation of senior preschool children's foreign language competence is carried out gradually in the process of interaction between teachers, parents and children under the following pedagogical conditions:

- the organization of a developing object-spatial educational environment;

- the use of a system of criteria for assessing children's foreign language competence, the peculiarities of parents' and teachers' communities in designing development activities;

- the application of modern technologies by teachers for establishing partnership with families.

In accordance with the research goal and hypothesis, the authors formulated the following objectives:

1. To identify the content and structure of a senior preschooler's foreign language competence based on the analysis of psycho-pedagogical and linguistic literature. 
2. To identify the potential for interaction between teachers, parents and children, as well as the specifics of the organization of pedagogical conditions in the process of learning a foreign language at an early age.

3. To determine the criteria and indicators, as well as diagnostic tools, for studying the formation of interaction participants' foreign language competence.

4. To develop a mechanism of interaction between the subjects of preschool education in the process of forming foreign language competence.

5. To substantiate the results of the research through quantitative and qualitative analysis.

The relevance of the research is determined by the social mandate, in which parents express a social need (for learning a foreign language) and teachers implement educational services at the state level in the process of children's education.

\section{Literature Review}

The relevance of the competence building approach is, first of all, viewed in the context of the implementation of the continuity principle in preschool and primary school education (BIM, 2007; MOROZOVA; REUTSKAYA, 2014). This provision is presented in the Report of the International Commission on Education for the 21st century, in which Jacques Delors et al. substantiate the need to review and expand the concept of continuing education (UNITED NATIONS EDUCATIONAL, SCIENTIFIC AND CULTURAL ORGANIZATION, 1996).

When examining senior preschool age, it is necessary to point out that a child's lifestyle is based on meaningful communication with adults and peers. The basic provisions on the role of communication were developed in the studies of Zaporozhets, Lisina (1974). The linguistic studies of domestic researchers (BIM, 2007; PROTASOA; RODINA, 2009; VORONOVA; MAYEVSKAYA, 2015; ZIMNYAYA, 2003) examine the aspects of the formation of senior preschool children's foreign language competence and the international tendency of early bilingual education. The methodological foundations for teaching English to senior preschool children, in particular, the substantiation of linguistic peculiarities and the pedagogical technologies in the field of early multicultural education are presented in the works of Mirolyubov (2010), Protasova (2016), Safonova (2017) and Tyasto (2015). 
Bim (2007), in his turn, notes a senior preschooler's 'foreign language communication competency' as a linguo-didactic and methodical category and defines it through the results of language learning, i.e. the ability and willingness to carry out interpersonal and intercultural communication in a foreign language with native speakers of the language; real practical mastery of a foreign language, which contributes to the development of the child's personality; the formation of the scientific image of the world, and critical thinking. Safonova (2017) defines 'foreign language competence' as the mastery level of linguistic, verbal and socio-cultural knowledge, skills and abilities that allow a child to demonstrate a communicative behavior depending on the factors of communication.

Consequently, the concepts of children's 'foreign language competence' and 'foreign language competency' are similar but not identical. It can be concluded that foreign language competencies are structural components of foreign language competence. Taking into account the definitions of 'senior preschool children's foreign language competence', the authors of the research will refer to this concept as a child's ability and willingness to carry our interpersonal and intercultural communication in a foreign language.

Highlighting the structural components of children's foreign language competence, the authors single out linguistic, socio-cultural, social, discursive and other competencies (SAFONOVA, 2017). Accordingly, taking into account the elaboration of these authors (BIM, 2007; SAFONOVA, 2017), it can be concluded that 'senior preschool children's foreign language competence' includes social, verbal, linguistic, socio-cultural and compensatory components - Table 1 (compiled by authors).

Table 1 - The structure of senior preschool children's language competence

\begin{tabular}{|c|c|c|c|c|}
\hline \multicolumn{5}{|c|}{ Senior preschool children's foreign language competence } \\
\hline $\begin{array}{l}\text { Linguistic } \\
\text { competency }\end{array}$ & $\begin{array}{l}\text { Compensatory } \\
\text { competency }\end{array}$ & $\begin{array}{c}\text { Verbal } \\
\text { competency }\end{array}$ & $\begin{array}{l}\text { Socio-cultural } \\
\text { competency }\end{array}$ & $\begin{array}{c}\text { Social } \\
\text { competency }\end{array}$ \\
\hline $\begin{array}{l}\text { A preschooler's } \\
\text { knowledge of } \\
\text { the linguistic } \\
\text { norms of a } \\
\text { foreign language, } \\
\text { in particular, } \\
\text { the basics of } \\
\text { phonetics, } \\
\text { vocabulary and } \\
\text { grammar. }\end{array}$ & $\begin{array}{l}\text { The ability to } \\
\text { use linguistic } \\
\text { and contextual } \\
\text { deduction, } \\
\text { to predict a } \\
\text { communicative } \\
\text { situation. }\end{array}$ & $\begin{array}{l}\text { The ability } \\
\text { to receive } \\
\text { and transmit } \\
\text { information } \\
\text { in a foreign } \\
\text { language; } \\
\text { to organize } \\
\text { and manage } \\
\text { communication. }\end{array}$ & $\begin{array}{l}\text { The ability } \\
\text { to feel an } \\
\text { emotional state; } \\
\text { expression of } \\
\text { feelings and } \\
\text { emotions in } \\
\text { one's own } \\
\text { communication. }\end{array}$ & $\begin{array}{l}\text { The ability to } \\
\text { interact with } \\
\text { an interlocutor; } \\
\text { mastery of } \\
\text { ways to enter } \\
\text { into a dialogue } \\
\text { and to predict } \\
\text { the reaction of } \\
\text { the partner. }\end{array}$ \\
\hline
\end{tabular}

Source: compiled by the authors (2018) 
It follows that senior preschoolers' foreign language competence has structural components that are related to the information, regulatory and affective elements. These characteristics of children's foreign language literacy are also noted in the research of Markussen-Brown et al. (2017). In this regard, the authors of the research outline the following criteria for assessing the competencies presented in Table 1: information-communication (assessment of the linguistic competency), regulatory-communication (assessment of the verbal, compensatory and social competencies) and affective-communication (assessment of the socio-cultural competency).

In accordance with the "Common European Framework of Reference: Learning, Teaching, Assessment", the assessment of senior preschoolers' foreign language proficiency for successful education in elementary school in Russia is characterized by Level A - Basic User, which includes A1 - Breakthrough and A2 - Waystage levels (LITTLE, 2007).

The studies of Gabdulchakov (2014), Mirolyubov (2010), Protasova (2016) and Steiner and Hayes (2008), made it possible to reveal the absence of a negative influence of foreign language learning on the development of senior preschool children's native language (Russian), in particular, the formation of metalinguistic consciousness, psychological language transfer, development of the concretization of language systems, etc. The analysis of modern foreign research shows the positive impact of foreign language learning on the development of children's speech, mental abilities, and socialization (KOCAMAN; KOCAMAN, 2012; TIMOSHENKO; OSPANOVA, 2016); the successful establishment and complementarity of a child's vocabulary (HOFF; QUINN; GIGUERE, 2017); speech modeling at the phonetic, grammatical, and lexical-stylistic levels, as well as clear verbal and "working memory" (PIERCE et al., 2017; ROJAS-BARAHONA et al., 2015; VERHAGEN; LESEMAN, 2016). This aspect ensures parents' and children's readiness for school and the development of early literacy and self-regulation skills (MARTI et al., 2018).

The modern elaboration of the Frank Porter Graham Child Development Institute (2015) made it possible to identify the fact that the qualitative foreign language learning at an early age increases the development level of children's language skills. The works of Lindholm-Leary (2014), Sawyer (2016) and Yazejian et al. (2015) discussed the formation of the susceptibility of linguistic phenomena, social and emotional skills of children below five years old, as well as self-confidence while communicating with other people. 
A teacher's professional skillfulness - the ability to encourage and guide children's communicative activity, ensuring an opportunity for creative study of language norms (BOWNE; YOSHIKAWA; SNOW, 2016; IRISKULOV, 2015; SHING, 2016), as well as the realization of continuity in the goals and content of preschool and primary education programs (GENESEE, 2015) - is of great importance (KIRILLOV; DEVYATYH; USHAKOVA, 2014).

Domestic and foreign scientific works reflect researchers' interest in the peculiarities of introducing effective techniques of teaching preschool children (RIBEIRO; ZACHRISSON; DEARING, 2017): work with an interactive blackboard, table and floor; multimedia presentation, Internet video resources and training; animation (KARAKAS, 2012; LAZĂR, 2015).

Accordingly, all areas of work with children have a single methodological basis: the substantiation of the linguistic peculiarities of languages studied the technologies of multi-cultural education (BIM, 2007; GANIMIAN; MURNANE, 2016; KHUSNULLINA, 2012; SPIEWAK TOUB et al., 2008; WALLACE; JACOBY; LESAUX, 2017).

When planning and designing educational activities, along with work activities such as quests, entertainment, promotions (REZZONICO et al., 2015), projects, exhibitions, festivals, quizzes, etc., traditional methods (learning songs, poems, plot and role plays, verbal didactic games) are used in combination with various types of creative activities for children (PROTASOVA; RODINA, 2009; UMURZAKOVA; MAHMUDOV, 2016).

Accordingly, the role of the teacher's personality significantly increases, which conditions the effectiveness and fecundity of the development of all interaction participants (CASTRO et al., 2017).

The theoretical analysis of the concept of "interaction" and its structures are presented in the works of Protasova (2016) and Rubleva (2016). Based on these theoretical provisions, "the interaction between preschool teachers and families" will be referred to as a unity of joint actions aimed at realizing the relevant tasks of the formation of children's foreign language competence.

Among the foreign studies on the interaction with families, the authors of the research point to Adler's model (2016), which is based on mutual respect, the rejection of dictate, an emphasis on equality and mutual responsibility, as well as the acceptance of individual characteristics and the family potential. Skinner 
(1987), Dreikurs (1993), initiated the formation of parents' discussion boards to share experiences, knowledge and information, the science of parent's behavior. The main goal of the empathic communication model of Rogers (1967) is to create a favorable atmosphere that will help parents and children express their feelings and emotions, as well as develop communication skills and sincerity in the communication with other people.

At the level of preschool education, modern approaches and technologies for realizing social and partnership relations were developed in Skudareva's (2016) research, in particular, models of social-psychological interaction with families; elaboration in the field of family language policy and bilingual education (BURSA, 2016; DZHALALOVA et al., 2017).

The studies of Afanasyev (2013), Justice, Jiang, Strasser (2018) and Bleses et al. (2018) present the influence of conditions and aspects of organizing a linguistic environment at home and in kindergarten. Based on literature analysis, it can be concluded that the effectiveness of forming senior preschool children's foreign language competence through the interaction between teachers and families depends on the creation of the following conditions:

- the organization of a developing subject-spatial educational environment in kindergarten and at home;

- the use of a system of criteria for assessing children's foreign language competence and the peculiarities of parents' and teachers' communities in designing development activities;

- the use of modern technologies by teachers to establish partnership with families.

\section{Materials and Methods}

To achieve the research goal, the authors used the following methods and techniques:

1. Theoretical analysis of literature; generalization of pedagogical experience; analysis of the practical creative activity of the employees of a preschool organization, parents and children at the Kindergarten No. 13 Topolek, a Municipal Budgetary Educational Institution in the town of Likino-Dulyovo in the Moscow Region, which provides the basis of this research. 
2. The empirical research included:

- the initial level and dynamics of interaction parties' foreign language competence were identified at the preparatory stage of practical work, which involved 100 children of senior preschool age (six years old): 55 preschoolers made up experimental groups (E1, E2, E3, E4, and E5 with 11 people for each year of study, the Kindergarten No. 13 Topolek, a Municipal Budgetary Educational Institution, Likino-Dulyovo, the Moscow Region); 55 people from Kindergarten No. 60 "Skazka", a Municipal Autonomous Preschool Educational Institution, were included in control groups (K1, K2, K3, K4, and K5 with 11 people for each year of study), as well as 65 people, the parents of children involved in experimental groups and employees of kindergartens: managers (two people), senior nursery teachers (two people), nursery teachers (15 people), 14 of whom were teachers of an experimental preschool organization. All the children were taught a foreign language in traditional settings in accordance with programs of supplementary education.

- The study of competencies by the criteria for assessing interaction participants' foreign language competence was carried out in accordance with the diagnostic procedure Protasova's program (PROTASOVA; RODINA, 2009). The authors of the research compiled maps of observations on preschoolers' foreign (English) language acquisition. The maps identified the percentage of children (adults) for each criteria, indicators (Table 3) and development levels of children's foreign language competence (low, medium and high). The quantitative analysis during data processing was based on the summation of points for each indicator: 1 point - low, 2 points - medium, and 3 points - high.

- the data obtained at the initial stage of foreign language learning (predominance of a low level of foreign language competence) determined the significance and relevance of a pedagogical mechanism of interaction between the subjects of preschool education (teachers, parents, and children);

- the main stage of practical work involved a total of 134 people: 55 senior preschoolers of experimental groups, 65 parents, and 14 employees of the experimental kindergarten.

The plan is designed for one year of study and includes the organization and implementation of pedagogical activities with duration of 30-40 minutes (Table 2: compiled by the authors). 
Table 2 - Designing a mechanism of interaction between the subjects of preschool education

\begin{tabular}{|c|c|c|c|}
\hline $\begin{array}{l}\text { Work } \\
\text { direction }\end{array}$ & $\begin{array}{l}\text { Implementation } \\
\text { of the interaction } \\
\text { mechanism } \\
\text { in accordance } \\
\text { with the work } \\
\text { direction. }\end{array}$ & $\begin{array}{l}\text { Stages of } \\
\text { establishing } \\
\text { interaction } \\
\text { with families }\end{array}$ & Technologies \\
\hline \multirow{2}{*}{$\begin{array}{l}\text { 1. Teacher } \\
\text { and parents }\end{array}$} & \multirow[b]{2}{*}{$\begin{array}{c}\text { Purposeful } \\
\text { pedagogical activity } \\
\text { to attract parents, } \\
\text { to establish mutual } \\
\text { understand and } \\
\text { common interests } \\
\text { in foreign language } \\
\text { learning. }\end{array}$} & 1. Opening & Doors open day etc. \\
\hline & & $\begin{array}{l}\text { 2. Clarifying } \\
\text { expectations }\end{array}$ & $\begin{array}{l}\text { Consultations of specialists of } \\
\text { children's public associations. }\end{array}$ \\
\hline \multirow[t]{3}{*}{$\begin{array}{l}\text { 2. Teacher } \\
\text { and children }\end{array}$} & \multirow{3}{*}{$\begin{array}{l}\text { Implementation } \\
\text { of pedagogical } \\
\text { activity using } \\
\text { modern } \\
\text { technologies of } \\
\text { working with } \\
\text { children. }\end{array}$} & 3. Coordination & $\begin{array}{l}\text { Diagnostics of the initial level of a } \\
\text { child's foreign language competence- } \\
\text { discussion of results. }\end{array}$ \\
\hline & & $\begin{array}{l}\text { 4. Interaction } \\
\text { design }\end{array}$ & Work with active parents, etc. \\
\hline & & $\begin{array}{l}\text { 5. Pedagogical } \\
\text { monitoring }\end{array}$ & $\begin{array}{l}\text { Master class "Kolobok" using puppet } \\
\text { theater; } \\
\text { Interactive game "Using Games in the } \\
\text { Process of Teaching English"; } \\
\text { Master class: "Teaching English } \\
\text { through the use of the finger game on } \\
\text { the topic 'My family"'; } \\
\text { "Contest of reading poems in English"; } \\
\text { KVN (Club of the Funny and Inventive } \\
\text { People), "Nature of Our Region"; } \\
\text { Joint creative activity "Our Hobbies" and } \\
\text { child-parent creative workshop; } \\
\text { Joint project activity "In the Circus" etc. }\end{array}$ \\
\hline $\begin{array}{l}\text { 3. Teacher, } \\
\text { parents, and } \\
\text { children }\end{array}$ & $\begin{array}{l}\text { Parents' } \\
\text { participation in } \\
\text { joint entertainment } \\
\text { activities. }\end{array}$ & 6. Reflection & $\begin{array}{l}\text { Final entertainment "ABC-Quiz" - } \\
\text { discussing the learning outcomes, } \\
\text { analyzing the results of joint activities. }\end{array}$ \\
\hline
\end{tabular}

Source: compiled by the authors (2018)

- observation at the final stage of the practical work - a study of family activity with the aim of studying the influence of parents' participation on the effectiveness of children's foreign language learning. At this stage of interaction, teacher and parents created a portfolio of children's success;

- the survey of parents (authorial survey "Assessment of Interaction") was aimed at revealing parents' attitude to the process of foreign language learning; 
- implementation of diagnostic methods aimed at studying the level of interaction parties' foreign language competence: authorial methods of studying a child's phonemic hearing, understanding a fairy-tale in English ("Little Bear" by Diane $\mathrm{Namm}$ ), lexical and grammatical skills of a foreign language, as well as proficiency in foreign language speaking; the technique "Assistants" (GOLOVEY; RYBALKO, 2002), the method of studying a child's personal behavior (GOLOVEY; RYBALKO, 2002), the technique "Reflection of Feelings" (GOLOVEY; RYBALKO, 2002), the sociometric test "Birthday" (GOLOVEY; RYBALKO, 2002), the "Game Room" technique (GOLOVEY, RYBALKO, 2002), drawing tests, and the "Lesenka" technique (GOLOVEY; RYBALKO, 2002).

For each of the identified criteria (information-communicative, regulatorycommunication, and affective-communicative), pedagogical and psychological diagnostic tools were selected - Table 3: compiled by the authors.

Table 3 - Diagnostic tools for studying the level of interaction participants' foreign language competence

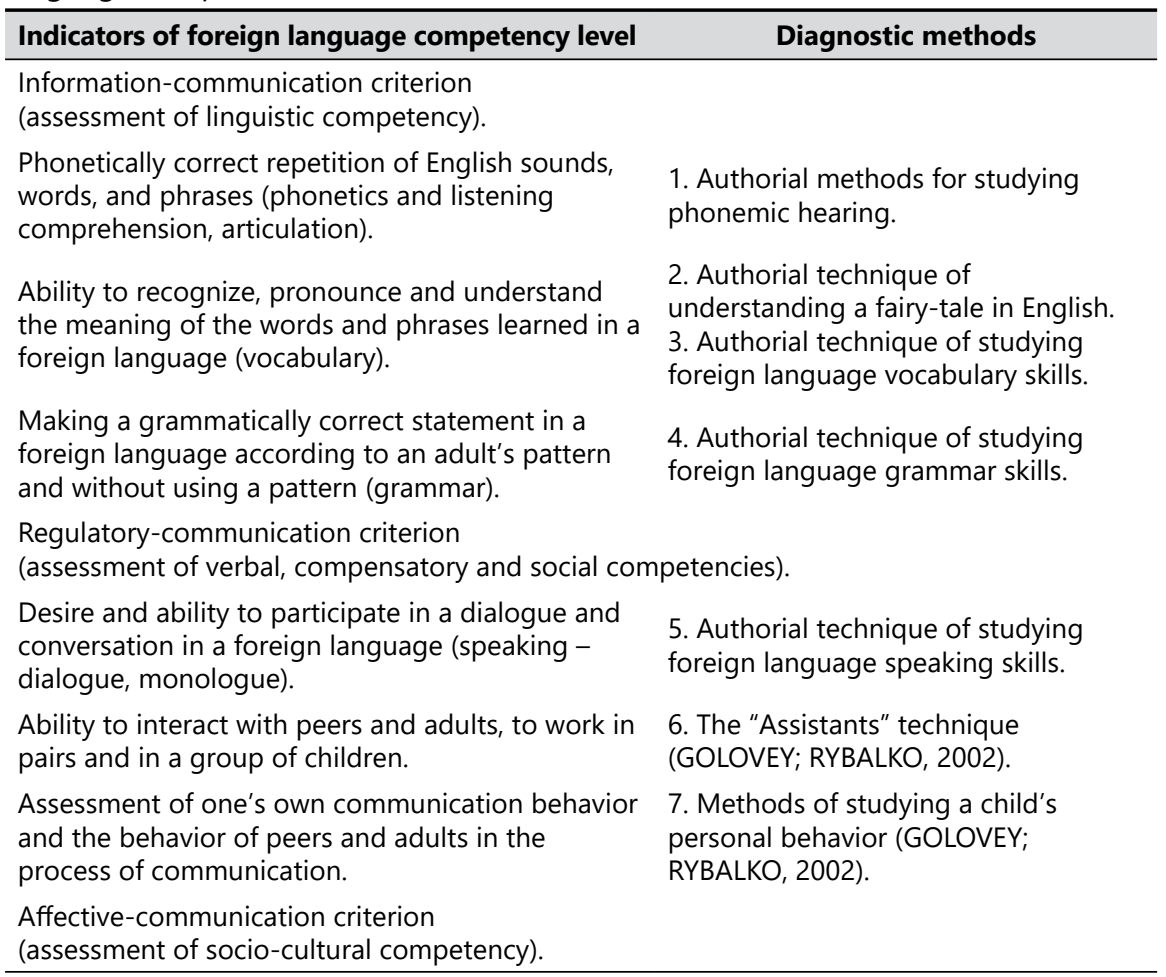


Continuation

Ability to demonstrate an emotional attitude to what a child wants to tell and to the communication participants.

8. The "Reflection of Feelings" technique (GOLOVEY; RYBALKO, 2002).

9. Sociometric test «Birthday»

Ability to express an emotional preference in (GOLOVEY; RYBALKO, 2002). communication.

10. The «Game Room» technique (GOLOVEY; RYBALKO, 2002).

Aspiration to communicate, accept and understand adults and peers.

11. Drawing tests.

12. The "Lesenka" technique (GOLOVEY; RYBALKO, 2002).

Source: compiled by the authors (2018)

The reliability of the research results is determined by the theoretical and methodological analysis of the research problem, the application of pedagogical and psychological diagnostic methods that correspond to the research goal, hypotheses and objectives, as well as by the comparative quantitative and qualitative analysis of the data of the practical work.

\section{Results}

Figure 1 (compiled by authors) presents the comparative results of the study of the initial development level of children's foreign language competence in experimental and control groups at the preparatory stage of the experimental work.

Figure 1 - Results of the study of the initial development level of children's foreign language competence in experimental and control groups ( $\mathrm{E}$ - experimental groups, $\mathrm{C}$ - control groups)

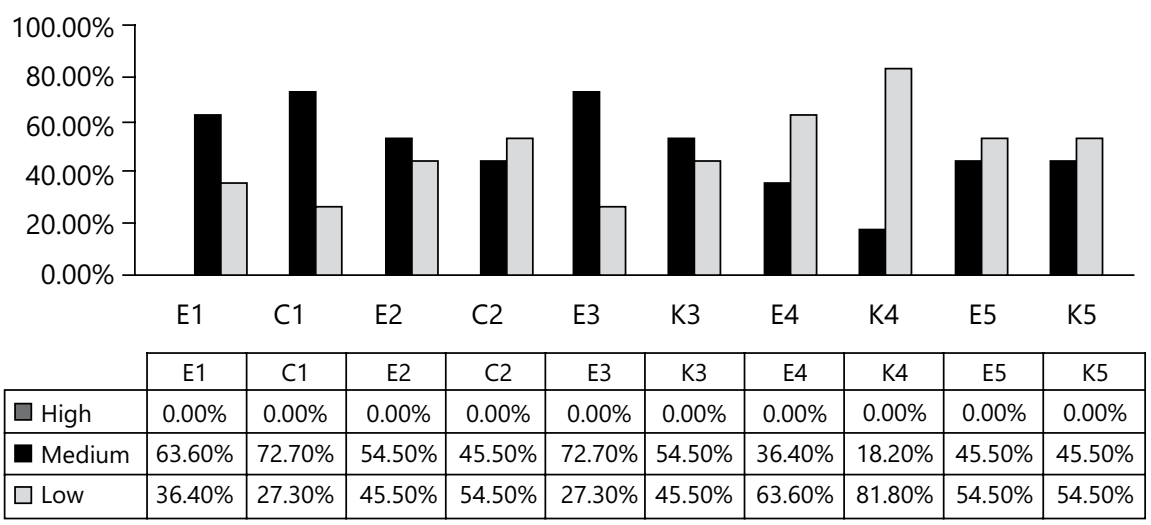

Source: compiled by the authors (2018) 
According to Figure 1, the research results showed a lack of high-level foreign language competence among the children of the experimental groups. A medium level of competencies prevailed in the experimental groups (E1 $-63.6 \%$, $\mathrm{E} 2-54.5 \%$, and E3 - 72.7\%). A medium level of competences prevailed in the control groups as well $(\mathrm{C} 1-72.7 \%, \mathrm{C} 3-54.5 \%)$. At the same time, a low level was observed in the experimental groups $\mathrm{E} 4-63.6 \%$ and $\mathrm{E} 5-54.5 \%$ and in the control groups $\mathrm{C} 2-54.5 \%, \mathrm{C} 4-81.8 \%$ and $\mathrm{C} 5-54.5 \%$. Accordingly, the authors of the research note a medium and a low level of foreign language competence in the experimental and control groups, respectively.

Below are the results of the study of the initial development level of foreign language competence among children's parents of experimental groups (Figure 2) and employees of the preschool organization (Figure 3): compiled by the authors.

Figure 2 - The results of the study of the initial development level of foreign language competence among children's parents of experimental groups $(1-$ informationcommunication criterion, 2 - regulatory-communication criterion, 3 - affectivecommunication criterion)

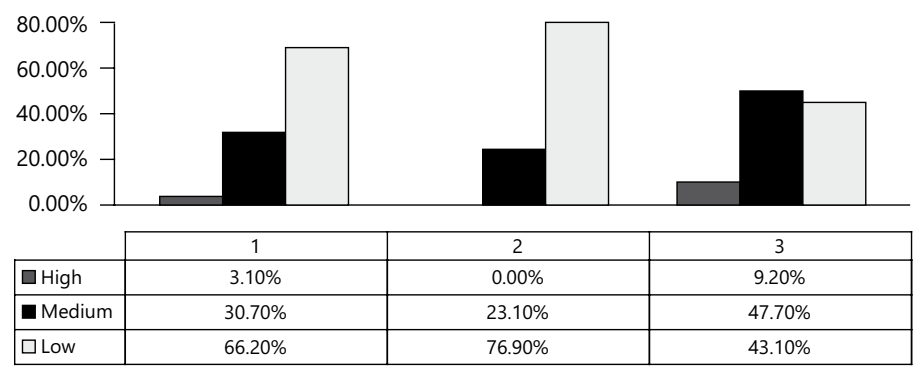

Source: compiled by the authors (2018)

Figure 3 - The results of the study of the initial development level of foreign language competence among the employees of the preschool organization (1 - informationcommunication criterion, 2 - regulatory-communication criterion, 3 - affectivecommunication criterion)

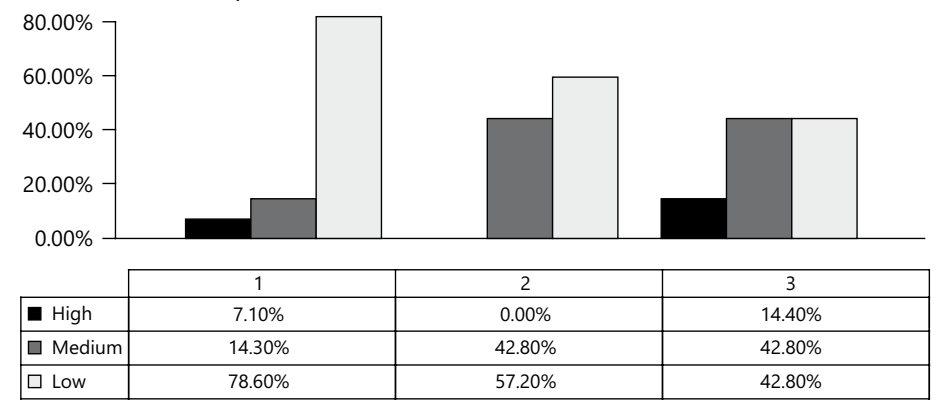

Source: compiled by the authors (2018) 
The results obtained (Figure 1-3) are quite predictable since the children, parents and kindergarten employees were at the initial stage of joint foreign language learning. In this regard, the authors of the research note the importance and relevance of designing a mechanism of interaction between the subjects of preschool education in the process of foreign language competence formation in accordance with work directions (Table 2).

At the end of the academic year, the authors determined the activity of parents through observation with the aim of studying the influence of family participation on the effectiveness of a child's foreign language learning (Figure 4: compiled by the authors).

Figure 4 - Research of parents' activity in the process of joint work by teachers and family ( 1 - established a positive influence of foreign language learning on a child's development; 2 - took an active part in activities; 3 - took part in joint creative activities)

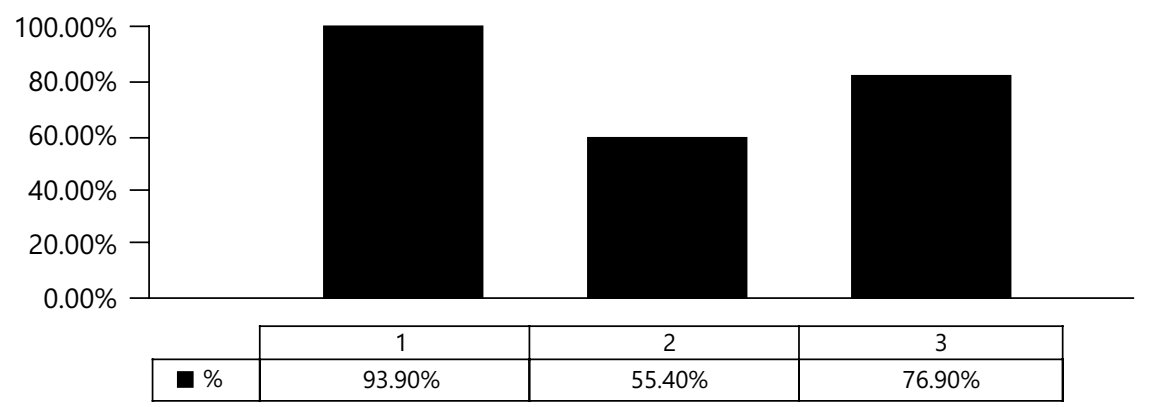

Source: compiled by the authors (2018)

According to the data presented in Figure 4, 55.4\% of parents (36 out of 65 ) took an active part in the preparation and organization of joint activities, in the performance of entertainment assignments at home, as well as in the creation of an evolving subject-spatial environment. $76.9 \%$ (50 out of 65 ) parents took part in joint creative activities.

At the stage of reflection, the authors of the research carried out a final survey of parents (authorial survey "Assessment of Interaction") (Figure 5: compiled by the authors). 
Figure 5 - Results of parents' final survey (1 - are satisfied with the teacher's work; 2 - liked participating in events; 3 - are aware of the child's results; 4 - took the teacher's recommendations into account; 5 - noted the child's willingness to learn the foreign language; 6 - are satisfied with the child's results)

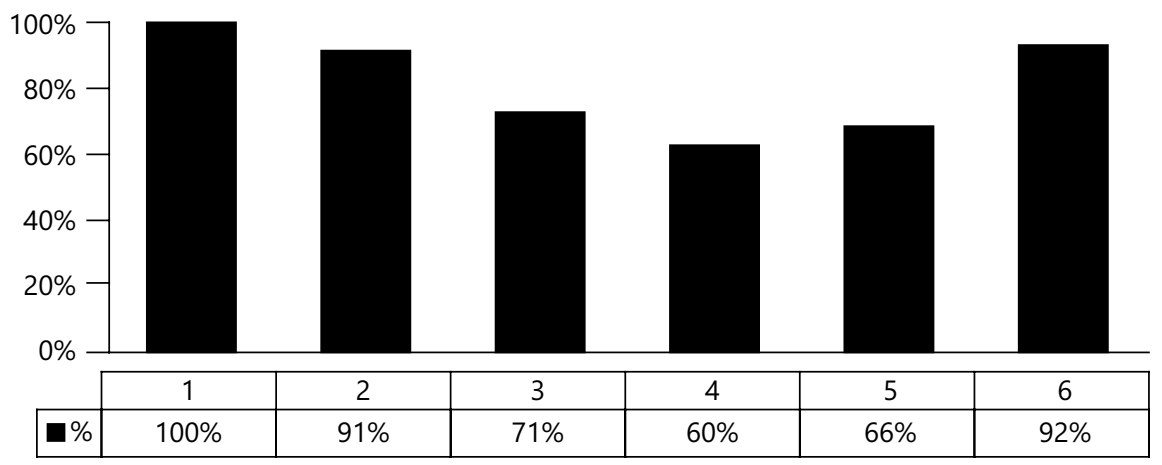

Source: compiled by the authors (2018)

According to the data presented in Figure 5, 90.8\% of parents (59 out of 65 ) liked taking part in events about the English language; $70.8 \%$ of parents (46 out of 65) were aware of their children's success and difficulties in the educational process, as well as the results of diagnostics; $60.0 \%$ of parents (39 out of 65) took into account the teacher's recommendations in the educational process; $66.1 \%$ of parents ( 43 out of 65 ) noted that the child enjoyed studying English at home, and $92.3 \%$ of parents (60 out of 65 ) were satisfied with their children's results.

The implementation of the mechanism of interaction made it possible to reconstruct the joint activity between parents and families, which lead to a positive dynamics in all the indicators of the level of children's foreign language competence.

The final stage of the experimental work was similar to the preparatory work. It consisted in studying senior preschool children's foreign language competence in the experimental (E1, E2, E3, E4 and E5) and control (C1, C2, C3, C4 and C5) groups: 110 people, the parents of children in the experimental groups (65 people) and employees of the experimental kindergarten (14 people).

Further, the results of the implementation of the techniques for identifying the level of foreign language competence among children in the experimental and control groups are shown in Figure 6 (compiled by the authors). 
Figure 6 - The results of studying the level of foreign language competence among children in the experimental and control groups ( $\mathrm{E}$ - experimental groups, $\mathrm{K}$ - control groups)

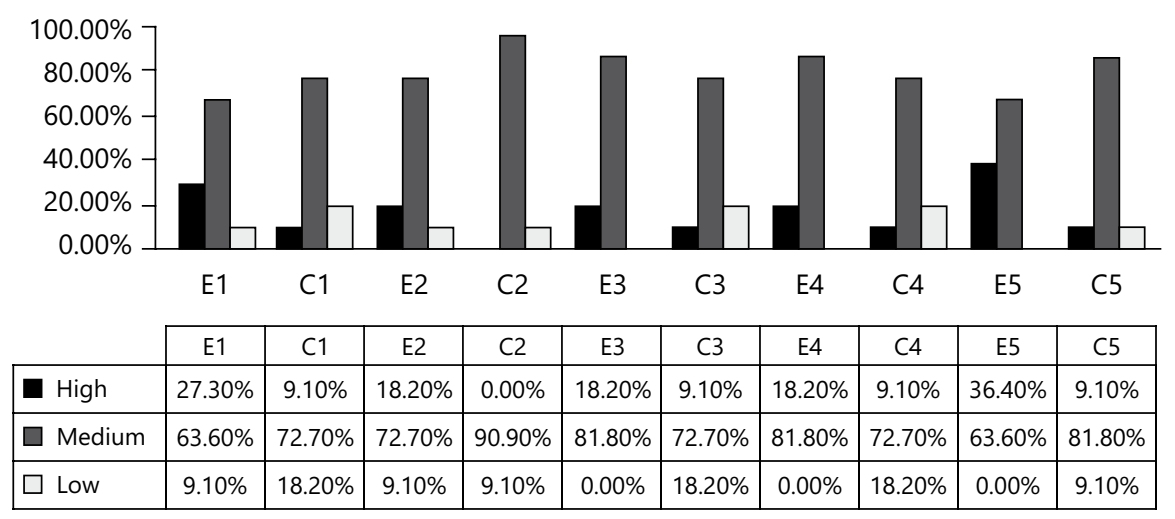

Source: compiled by the authors (2018)

According to Figure 6, a high level was observed mainly in the experimental groups (E1 - 27.3\%, E2 - 18.2\%, E3 - 18.2\%, E4 -18, 2\% and E5 - 36.4\%), while only a single child showed a high level $(9.1 \%)$ in $\mathrm{C} 1, \mathrm{C} 2, \mathrm{C} 3, \mathrm{C} 4$ and $\mathrm{C} 5$ control groups. The authors of the research recorded a predominance of the medium level in the experimental groups: E1 - 63.6\%, E2 - 72.7\%, E3 - 81.8\%, E4 - 81.8\% and $\mathrm{E} 5-63.6 \%$. The control groups were also characterized by a medium level: $\mathrm{C} 1, \mathrm{C} 3$ and $\mathrm{C} 4-72.7 \%, \mathrm{C} 2-90.9 \%$, and $\mathrm{C} 5-81.8 \%$. The control stage of the experiment showed that all study groups involved children with the low level $(9.1 \%)$ that was demonstrated by a single child in E1 and E2 experimental groups. Meanwhile, the indicators of low level competence were much higher in the control groups: $\mathrm{C} 1, \mathrm{C} 3, \mathrm{C} 4-18.2 \%, \mathrm{C} 2$ and $\mathrm{C} 5-9.1 \%$. Based on the results of the quantitative and qualitative analysis, the authors of the research come to the conclusion that the experimental groups coped with the established tasks more successfully than the control groups.

Figures 7 and 8 (compiled by the authors) present the results of studying the foreign language competence level of the parents of children in the experimental groups and the employees of the experimental kindergarten. 
Figure 7 - The results of studying the foreign language competence level of the parents of children in the experimental groups ( 1 - information-communication criterion, 2 - regulatory-communication criterion, 3 - affective-communication criterion)

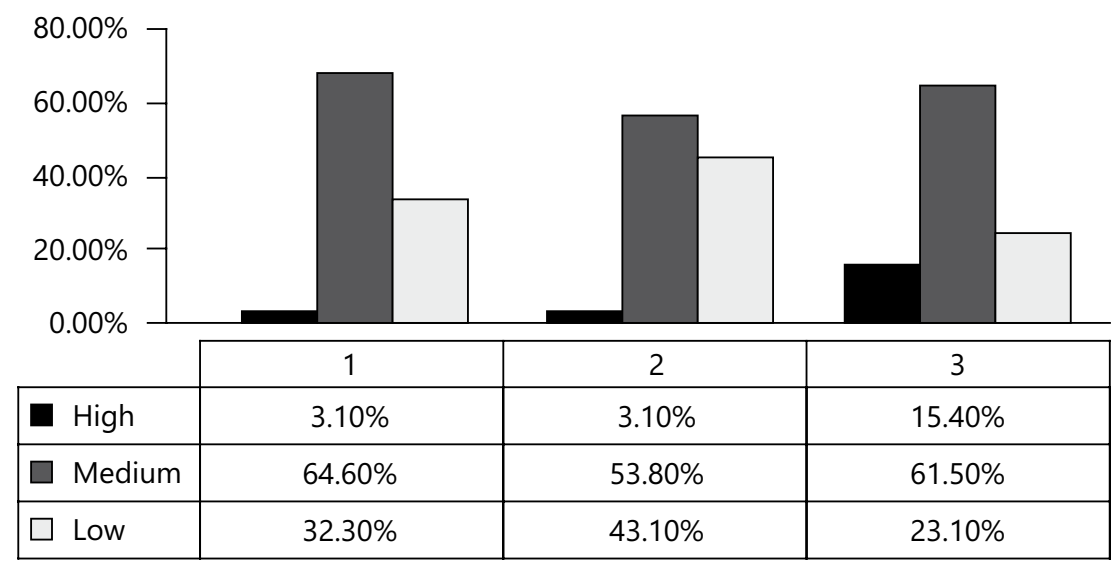

Source: compiled by the authors (2018)

Figure 8 - The results of studying the foreign language competence level of the employees of the preschool organization (1 - information-communication criterion, 2 - regulatory-communication criterion, 3 - affective-communication criterion)

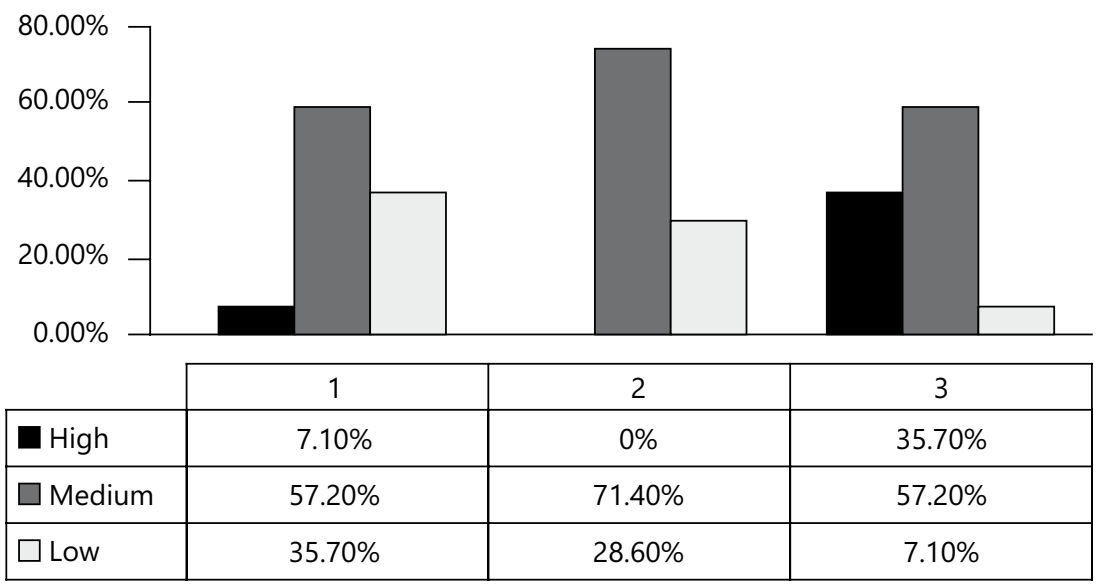

Source: compiled by the authors (2018)

According to Figures 7 and 8, at the final stage of the research, a medium level of foreign language competence prevailed among the parents and teachers - unlike the preparatory stage, in which a low level prevailed. 


\section{Discussion}

The process of communication in the native (Russian) and foreign (English) languages, joint activities with adults and peers, as well as independent gaming and other kinds of activities, is accompanied by the formation of a senior preschooler's foreign language competence: Bim (2007), Spiewak Toub et al. (2018) and Zaporozhets and Lisina (1974).

Through the analysis of the joint work with parents in the preparatory stage of the experiment, the authors of the research revealed psychological anxiety towards the perception of a foreign language among parents, as well as doubts concerning whether preschool children are able to assimilate material in a foreign language due to the poor understanding of certain phrases and utterances in the foreign language. Nevertheless, the observation of children in the process of educational activity revealed openness, emotionality, intellectual curiosity, an interest and a desire to earn new words, phrases and statements in English.

Consequently, the interaction between the subjects of preschool education goes through several stages of development: the identification of mutual goals, the interests of the parties, the identification of opportunities, the needs for learning a foreign language, and the involvement in dynamic joint activities; realization of interaction; transition to trust-based relations of the parties; the achievement of mutual support and a positive psychological attitude in the learning process. The only problem that the authors of the research had to encounter was the predominant number of parents who neither spoke nor ever studied English. This problem is also indicated in the studies of Bursa (2016). Despite this fact, the majority of the parents attended the events and fulfilled the teacher's requirements and recommendations concerning the child's learning process at home.

The final stage of the practical work was to make a conclusion about the positive dynamics in the development of preschooler's foreign language competence. Meanwhile, based on the fact that the interaction between the teachers and parents in these groups was spontaneous, unsystematic, without the full inclusion of the parents' collective, the authors of the research assume that families had difficulties in the process of foreign language learning in primary school.

Consequently, the results of the qualitative analysis of senior preschoolers' performance of diagnostic tasks evidence the success of children of the experimental groups since the parents of the children were actively involved in the kindergarten's educational activity towards teaching English (CASTRO et al., 2017). 
The mechanism of interaction between teachers and parents made it possible to create conditions for the joint organization of a developing subject-spatial educational environment; the use of a system of criteria and indicators for assessing children's foreign language competence, the peculiarities of parents' and teacher's communities in the planning and implementation of developing activities, as well as for the application of modern technologies by kindergarten teachers for establishing partnership with families.

The empirical data showed that, in addition to having a significant impact on the development level of children's foreign language competence, parents' activity and participation lead to an increase in motivation, a positive attitude, as well as the family's openness to study languages, on the readiness of children and their families for more conscious foreign language learning at the next stage of education. Thus, the authors of the research revealed and empirically studied the pedagogical conditions for the formation of senior preschool children's foreign language competence.

\section{Conclusions}

The research gives an understanding of the problem of forming senior preschool children's foreign language competence in the pedagogical theory and practice, as well as the realization of potential opportunities for interaction between the subjects of preschool education.

The authors of the research substantiate the methodical recommendations, the use of which allows improving the quality of the pedagogical activity of kindergarten employees through creating and organizing the pedagogical conditions singled out. The authors developed a system of criteria and diagnostic tools - including authorial techniques - for studying the development level of foreign language competence among the participants of the interaction.

The relevance of the research problem in the practical work of kindergarten allowed designing a mechanism of interaction between the subjects of preschool education according to the stages singled out by the authors and areas of joint activity, using modern technologies of working with parents and children. This made it possible to create and practically implement the pedagogical conditions for the formation of senior preschool children's foreign language competence.

The prospects of the research are obvious: the theory and practice of senior preschool children's foreign language education require approbation through 
organizing special courses aimed at preparing bachelors of Pedagogical Education, as well as courses aimed at the improvement of the professional skills of pedagoguemethodologists in kindergartens and primary schools.

\section{Acknowledgements}

The authors of the research express their gratitude to the State educational institution of higher professional education Moscow region, the State University of Humanities and Technology in Orekhovo-Zuevo, the Moscow Region of the Russian Federation for the financial support within the framework of the competition of intramural research projects "Small Grant of the State University of Humanities and Technology". 


\section{Condições pedagógicas para a formação da competência em línguas estrangeiras de crianças em idade pré-escolar}

\section{Resumo}

O objetivo da pesquisa é identificar, fundamentar teoricamente e estudar empiricamente as condições pedagógicas para a formação da competência em língua estrangeira de pré-escolares. Os métodos consistem em procedimentos de diagnóstico autoral que visam a estudar a competência em línguas estrangeiras dos participantes da interação. A pesquisa identificou as especificidades da interação entre sujeitos de educação pré-escolar. Os autores revelaram a influência da participação dos pais na competência, motivação, atitude e abertura para aprender línguas estrangeiras, bem como a ansiedade psicológica dos pré-escolares em relação à percepção da fala estrangeira. Os autores expandiram as idéias sobre a formação da competência de língua estrangeira das crianças pré-escolares em teoria e prática pedagógica e sobre a realização das oportunidades de interação dos participantes com base na parceria sócio-pedagógica, que permite melhorar as atividades conjuntas entre as organizações pré-escolares modernas e familiares.

Palavras-chave: Abordagem de construção de competências. Competência em língua estrangeira dos pré-escolares. Aprendizagem precoce de linguas estrangeiras. Interação entre professores de pré-escola e familiares.

\section{Condiciones pedagógicas para la formación de la competencia en idiomas extranjeros para niños en edad preescolar}

\section{Resumen}

El objetivo de la investigación es identificar, fundamentar teóricamente y estudiar empíricamente las condiciones pedagógicas para la formación de la competencia en idiomas extranjeros para preescolares de edad avanzada. Los métodos consisten en procedimientos de diagnóstico de autor para estudiar la competencia en el idioma extranjero de los participantes de interacción. La investigación identificó los aspectos específicos de la interacción entre los sujetos de educación preescolar. Los autores revelaron la influencia de la participación de los padres en la competencia, la motivación, la actitud y la apertura de las lenguas extranjeras para aprender idiomas, así como la ansiedad psicológica de los preescolares hacia la percepción del habla extranjera. Los autores ampliaron las ideas sobre la formación de la competencia en el idioma extranjero de los niños en edad preescolar en la teoría y la práctica pedagógica y en la realización de las oportunidades de interacción de los participantes sobre la base de la asociación social y pedagógica, que permite mejorar las actividades conjuntas entre organizaciones modernas de preescolar y familias.

Palabras clave: Enfoque de construcción de competencias. La competencia en idiomas extranjeros de preescolares de alto nivel. Aprendizaje temprano de lenguas extranjeras. Interacción entre maestros preescolares y familiares. 


\section{References}

ADLER, A. The education of children. London: Routledge, 2016.

AFANASYEV, V. V. Monitoring as a special kind of scientific theory and practice. Scientific Notes: Electronic Scientific Journal of Kursk State University, Kursk, v. 26, n. 2, p. 1-4, 2013.

BIM, I. L. Competence building approach to education and foreign language learning. In: KHUTORSKY, A. V. (ed.). Competencies in education: design experience. Moscow: Scientific and Innovative Enterprise, 2007. p. 374.

BLESES, D. et al. Effective language and literacy instruction: evaluating the importance of scripting and group size components. Early Childhood Research Quarterly, [s. l.], v. 42, p. 256-269, Jan./Mar. 2018. https://doi.org/10.1016/j.ecresq.2017.10.002

BORISOVA, N. B. Innovative activity in a preschool educational organization is the key to its competitiveness in the market of educational services. Universum: Psychology and Education, [s. l.], v. 28, n. 10, 2016.

BOWNE, J. B.; YOSHIKAWA, H.; SNOW, C. E. Relationships of teachers' language and explicit vocabulary instruction to students' vocabulary growth in kindergarten. Reading Research Quarterly, Newark, v. 52, n. 1, p. 7-29, Jan./Mar. 2016. https://doi.org/10.1002/rrq.151

BURSA, A. European project on cooperation with the family concerning problems of bilingualism. In: ANTONOVA, N.; PROTASOVA, E.; SIRKIYA, Y. (eds.). Returning to bilingualism in russian kindergartens: regional experience. Helsinki: Suomi-Venäjä-Seura, 2016. p. 173-186.

CASTRO, D. C. et al. Early education of dual language learners: an efficacy study of the nuestros niños school readiness professional development program. Early Childhood Research Quarterly, Washington, DC, v. 40, p. 188-203, July/Sept. 2017. https://doi.org/10.1016/j.ecresq.2017.03.002

DREIKURS, R.; GREY, L. Logical consequences: a new approach to discipline. New York: Plume, 1993.

DZHALALOVA, A. et al. Family language policy and bilingual education. In: PROTASOVA, E. Y. (ed.). Bilingualism and environment. Berlin: Retorika, 2017. p. 8-45. 
FRANK PORTER GRAHAM CHILD DEVELOPMENT INSTITUTE. Early education narrows the achievement gap with younger starts and longer stays. Science Daily, [s.1.], 2015 Mar. 31. Available at: https://www.sciencedaily. com/releases/2015/03/150331121624.htm. Accessed on: 2018 June 16.

GABDULCHAKOV, V. F. Multicultural language development of preschool children in Russia. Procedia: Social and Behavioral Sciences, [s. l.], v. 146, p. 222-5, Aug. 2014. https://doi.org/10.1016/j.sbspro.2014.08.118

GANIMIAN, A. J.; MURNANE, R. J. Improving education in developing countries. Review of Educational Research, Washington, DC, v. 86, n. 3, p. 719-755, 2016. https://doi.org/10.3102/0034654315627499

GENESEE, F. North america rethinking early childhood education for English language learners: the role of language. London: British Council, 2015. Available at: https://www.mcgill.ca/psychology/files/psychology/genesee_ ece_march_10_2015_in_press.pdf. Accessed on: 2018 June 16.

GOLOVEY, L. A.; RYBALKO, E. F. (eds.). Workshop on age psychology: manual. St. Petersburg: Rech, 2002.

HOFF, E.; QUINN, J.; GIGUERE, D. What explains the correlation between growth in vocabulary and grammar? New evidence from latent change score analyses of simultaneous bilingual development. Developmental Science, [s. l.], v. 21, n. 2, p. 1-28, 2017. https://doi.org/10.1111/desc.12536

IRISKULOV, M. Teaching foreign languages at pre-school educational institutions. Foreign Languages in Uzbekistan, [s. l.], v. 7, n. 3, p. 93-97, 2015.

JUSTICE, L. M.; JIANG, H.; STRASSER, K. Linguistic environment of preschool classrooms: what dimensions support children's language growth? Early Childhood Research Quarterly, Washington, DC, v. 42, p. 79-92, Jan./ Mar. 2018. https://doi.org/10.1016/j.ecresq.2017.09.003

KARAKAS, R. The use of cartoons for developing the skills of understanding and analyzing of children in preschool period. Procedia: Social and Behavioral Sciences, [s. l.], v. 46, p. 3026-3030, 2012.

KHUSNULLINA, R. R. New technology in teaching foreign language: traditions and innovations in teaching english. In: INTERNATIONAL CONFERENCE, 2012, Kazan. Proceedings[...] Kazan, 2012. p. 55-8. 
KIRILLOV, I. L.; DEVYATYH, S. Y.; USHAKOVA, O. S. Preschool education in a country and the world: historical preschool education in a country and the world: historical experience, state and prospects experience, state and prospects. In: INTERNATIONAL SCIENTIFIC CONFERENCE, 3, 2014, Prague. Materials[...] Prague: Vědeckovyda- deckovydavatelské centrum «Sociosféra-CZ», 2014.

KOCAMAN, O.; KOCAMAN, N. Age factor in foreign language education at preschool level. Procedia: Social and Behavioral Sciences, [s. l.], v. 55, p. 168-177, 2012. https://doi.org/10.1016/j.sbspro.2012.09.491

KREN, A. A.; VOVK, E. V. Analysis of the concept "senior preschoolers' communicative competence" in modern literature. Universum: Psychology and Education, [s. l.], v. 48, n. 6, 2018.

LAZĂR, A. Pre-primary educators and the use of digital resources to raise early foreign language awareness. Procedia: Social and Behavioral Sciences, [s. l.]. v. 180, p. 841-846, May 2015. https://doi.org/10.1016/j.sbspro.2015.02.221

LINDHOLM-LEARY, K. Bilingual and biliteracy skills in young Spanish-speaking low-SES children: impact of instructional language and primary language proficiency. International Journal of Bilingual Education and Bilingualism, [s. l.], v. 17, n. 2, p. 144-159, 2014. https://doi.org/10.1080/13670050.2013.866625

LITTLE, D. The common european framework of reference for languages: perspectives on the making of supranational language education policy. The Modern Language Journal, Monterey, v. 91, n. 4, p. 641-653, 2007. https://doi.org/10.1111/j.1540-4781.2007.00627_2.x

MARKUSSEN-BROWN, J. et al. The effects of languageand literacy-focused professional development on early educators and children: a best-evidence meta-analysis. Early Childhood Research Quarterly, Washington, DC, v. 38, p. 97-115, Jan./Mar. 2017. https://doi.org/10.1016/j.ecresq.2016.07.002

MARTI, M. et al. Intervention fidelity of getting ready for school: associations with classroom and teacher characteristics and preschooler's school readiness skills. Early Childhood Research Quarterly, Washington, DC, v. 44, p. 55-71, July/Sept. 2018. https://doi.org/10.1016/j.ecresq.2018.02.010 
MCCOY, D. C. et al. Measuring early childhood development at a global scale: evidence from the caregiver-reported early development instruments. Early Childhood Research Quarterly, Washington, DC, v. 45, p. 58-68, Oct./Dec. 2018. https://doi.org/10.1016/j.ecresq.2018.05.002

MIROLYUBOV, A. A. (ed.). Methods of teaching foreign languages: traditions and modernity. Obninsk: Titul, 2010.

MOROZOVA, N. A.; REUTSKAYA, N. A. On the problem of implementing the competence approach in preschool education. Upbringing and Education of Young Children, [s. l.], n. 2, p. 1-7, 2014.

PIERCE, L. et al. Variations in phonological working memory: linking early language experiences and language learning outcomes. Applied Psycholinguistics, Cambridge, v. 38, n. 6, p. 1265-1300, 2017. https://doi.org/10.1017/S0142716417000236

PIERCE, L. et al. Some international trends in early bilingual education. The Russian Language Abroad, [s. l.], v. 6, p. 4-10, 2016.

PROTASOVA, E. Y.; RODINA, N. M. Teaching a foreign language to preschool children: program "little by little". Moscow: Karapuz-Didaktika, 2009.

REZZONICO, S. et al. Improving preschool educators' interactive shared book reading: effects of coaching in professional development. American Journal of Speech-Language Pathology, Rockville, v. 24, n. 24, p. 717-32, Nov. 2015. https://doi.org/10.1044/2015_AJSLP-14-0188.

RIBEIRO, L. A., ZACHRISSON, H. D., DEARING, E. Peer effects on the development of language skills in norwegian childcare centers. Early Childhood Research Quarterly, Washington, DC, v. 41, p. 1-12, Oct./Dec. 2017. https://doi.org/10.1016/j.ecresq.2017.05.003

ROGERS, C. R. et al. Person to person: the problem of being human: a new trend in psychology. Lafayette: Real People, 1967.

ROJAS-BARAHONA, C. A. et al. Improvement of working memory in preschoolers and its impact on early literacy skills: a study in deprived communities of rural and urban areas. Early Education and Development, [s. l.], v. 26, n. 5-6, p. 871-92, 2015. https://doi.org/10.1080/10409289.2015.1036346 
RUBLEVA, Y. Y. The essence of pedagogical interaction as a factor in the development of all participants in the educational process. Mir Nauki, [s. l.], v. 4, n. 3, p. 1-18, 2016.

SAFONOVA, V. V. Children's cultural studies as an integral part of modern primary language education in Russia. Foreign Languages in School, [s. l.], n. 12, p. 3-16, 2017.

SAWYER, J. In what language do you speak to yourself? A review of private speech and bilingualism. Early Childhood Research Quarterly, Washington, DC, v. 36, p. 489-505, July/Sept. 2016. https://doi.org/10.1016/j.ecresq.2016.01.010

SHING, R. W. K. Do Hong Kong pre-school teachers of English engage in learning and teaching activities conducive to young children's vocabulary development? In: MURPHY, V. A.; EVANGELOU, M. (eds.). Early childhood education in english for speakers of other languages. London: British Council, 2016. p. 195-206.

SKINNER, B. F. Whatever happened to psychology as the science of behavior. American Psychologist, Washington, DC, v. 42, n. 8, p. 780-786, 1987. https://doi.org/10.1037/0003-066X.42.8.780

SKUDAREVA, G. N. Modern ideas about public participation in Russian education. Newsletter of the Kostroma State University, 2016. Available at: https://cyberleninka.ru/article/n/sovremennye-predstavleniyaobobschestvennom-uchastii-v-rossiyskom-obrazovanii. Accessed on: 2017 May 10.

SPIEWAK TOUB, T. et al. The language of play: developing preschool vocabulary through play following shared book-reading. Early Childhood Research Quarterly, Washington, DC, v. 45, p. 1-17, Oct./Dec. 2018. https://doi.org/10.1016/j.ecresq.2018.01.010

STEINER, N.; HAYES, S. L. 7 steps to raising a bilingual child. New York: American Management Association, 2008.

TIMOSHENKO, V. I.; OSPANOVA, V. A. Problems of early learning in foreign language education. Bulletin of the Karagand a University, 2016. Available at: https://articlekz.com/en/article/14566. Accessed on: 2018 June 19. 
TYASTO, A. A. Games as a means of developing foreign language skills. Young Researcher, [s. l.], v. 2, p. 561-562, 2015.

UMURZAKOVA, D. I.; MAHMUDOV, S. I. The role of clubs in learning foreign languages. Nauchnyi Almanakh, [s. l.], v. 17, n. 3-2, p. 308-310, 2016. Available from: http://ucom.ru/doc/na.2016.03.02.308.pdf. Accessed on: August 9, 2018.

\section{UNITED NATIONS EDUCATIONAL, SCIENTIFIC AND CULTURAL} ORGANIZATION - Unesco. Learning: the treasure within. In: INTERNATIONAL COMMISSION ON EDUCATION FOR THE 21ST CENTURY, 1996, Moscow. Proceedings[...] New York, 1996. Available from: http://www.ifap.ru/library/book201.pdf. Accessed on: March 13, 2018.

VERHAGEN, J.; LESEMAN, P. How do verbal short-term memory and working memory relate to the acquisition of vocabulary and grammar? A comparison between first and second language learners. Journal of Experimental Child Psychology, [s. l.], v. 41, p. 65-82, Jan. 2016. https://doi.org/10.1016/j.jecp.2015.06.015, 2016.

VORONOVA, L. S.; MAYEVSKAYA, A. Y. Foreign language communicative competence and its component competencies. Relevant Problem in Humanities and Natural Sciences, n. 2, 2015. Available from: http://booksc.org/ ireader/50289052. Accessed on: 2018 April 10.

WALLACE JACOBY, J.; LESAUX, N. K. Language and literacy instruction in preschool classes that serve latino dual language learners. Early Childhood Research Quarterly, Washington, DC, v. 40, p. 77-86, July/Sept. 2017. https://doi.org/10.1016/j.ecresq.2016.10.001

YAZEJIAN, N. et al. High-quality early education: age of entry and time in care differences in student outcomes for English-only and dual language learners. Early Childhood Research Quarterly, Washington, DC, v. 32, p. 23-39, July/Sept. 2015. https://doi.org/10.1016/j.ecresq.2015.02.002

ZAPOROZHETS, A. V.; LISINA, M. I. The development of preschoolers' communication. Moscow: Pedagogy, 1974. Available from: http://psychlib.ru/ mgppu/Zro-1974/Zro-288.htm\#\$p1. Accessed on: 2017 July 10.

ZIMNYAYA, I. A. A person's competence: a new quality of education results. Modern Higher Education, [s. l.], n. 5, p. 34-42, 2003. 


\section{Information about authors}

Rania Gennadievna Izmailova: Ph.D. in Pedagogical Sciences, Associate Professor, Head of the Department of Theory and Methodology of Primary and Preschool Education, Moscow State University of Humanities and Technology. Contact: izmailova.sei@rambler.ru

(iD) https://orcid.org/0000-0001-5562-6551

Tatyana Gennadievna Sheinova: Ph.D. in Pedagogical Sciences, Associate Professor, Department of Theory and Methodology of Primary and Preschool Education, Moscow State University of Humanities and Technology. Contact: sheinova.sei@rambler.ru

(iD) https://orcid.org/0000-0001-7247-7412

Ksenia Yurievna Soldatenko: Assistant, Department of Theory and Methodology of Primary and Preschool Education, Moscow State University of Humanities and Technology. Contact: soldatenko.sei@bk.ru

iD https://orcid.org/0000-0002-5793-2277 